\title{
Edukasi Perilaku Hidup Bersih dan Sehat (PHBS) dalam Pencegahan dan Pengendalian Covid-19 pada Anak-Anak Tk
}

\author{
Icka Irma, Icca Stella Amalia, Iding Budiman, Elina Haqie, Regia Rohmania Putri, Rita Nuryati, Nita \\ Agustina Sari \\ STIKes Kuningan
}

Email: ickairma22@gmail.com

Pendahuluan: Peristiwa menyebarnya penyakit virus korona2019 di seluruh dunia menyebabkan kematian. Hasil wawancara dengan Kepala Taman Kanak-kanak (TK) Fajar Indah diperoleh informasi bahwa dalam masa pandemi COVID-19 saat ini, anak-anak sangat membutuhkan pendampingan dalam menerapkan perilaku hidup bersih dan sehat selama masa pandemi COVID-19 karena tingginya resiko untuk terpapar penyakit. Tujuan: kegiatan pengabdian masyarakat ini bertujuan untuk mengubah perilaku hidup bersih dan sehat di masa Pandemi Covid-19. Metode: Edukasi dilakukan dengan menggunakan metode kaji tindak dengan pendekatan program tindak partisipatif melalui ceramah, tanya jawab, diskusi, dan demonstrasi. Penyampaian materi juga diberikan melalui perlombaan mewarnai dan penjelasan menggunakan poster bergambar pada proses pembelajaran. Adapun sasaran pada kegiatan ini yaitu anak-anak Taman Kanak-kanak (TK) Fajar Indah Desa Cipaku sebanyak 51 orang. Hasil: Hasil kegiatan menunjukkan bahwa edukasi yang diberikan oleh fasilitator dapat meningkatkan pengetahuan anak-anak TK Fajar Indah terhadap perilaku hidup bersih dan sehat dalam pencegahan COVID-19 ( $\mathrm{p}<$ $0,05)$. Hal ini ditunjukkan pada peningkatan nilai peserta setelah dilaksanakannya penyuluhan, sebagian besar peserta memiliki tingkat pengetahuan baik yaitu sebanyak 41 orang $(80.4 \%)$ dan berpengetahuan cukup sebanyak 10 orang (19.6\%). Kesimpulan: ada pengaruh penyuluhan terhadap tingkat pengetahuan anak-anak TK Fajar Indah.

Kata Kunci : PHBS, COVID-19, Edukasi, Physical Distancing, Taman Kanak-Kanak, Desa Cipaku

\section{PENDAHULUAN}

Pandemi COVID-19 adalah peristiwa menyebarnya penyakit koronavirus 2019 (bahasa Inggris: coronavirus disease 2019, disingkat COVID-19) di seluruh dunia. Penyakit ini disebabkan oleh koronavirus jenis baru yang diberi nama SARS-CoV-2. Wabah COVID-19 pertama kali dideteksi di Kota Wuhan, Provinsi Hubei, Tiongkok pada bulan Desember 2019, dan ditetapkan sebagai pandemi oleh Organisasi Kesehatan Dunia (WHO) pada 11 Maret 2020. Penyakit ini ditularkan melalui droplet (percikan) pada saat berbicara, batuk, dan bersin dari 
orang yang terinfeksi virus Corona. Selain itu penyakit ini juga dapat ditularkan melalui kontak fisik (sentuhan atau jabat tangan) dengan penderita serta menyentuh wajah, mulut, dan hidung oleh tangan yang terpapar virus Corona (Singhal, 2020).

Jumlah kasus COVID-19 semakin berkembang dari waktu ke waktu. Saat ini, menurut data yang dilansir oleh kawalcovid19.id bahwa per tanggal 27 September 2021 tercatat di Indonesia ada 4.201.403 kasus terkonfirmasi positif dan juga dilaporkan 4.027.548 orang sembuh, 40.270 orang dalam perawatan serta 141.585 orang lainnya dinyatakan meninggal (Kawal Covid-19, 2021). Adapun jumlah kasus terkini di Jawa Barat total 702.067 terkonfirmasi positif, 683.926 orang dinyatakan sembuh, 3.546 orang dalam perawatan, dan 14.596 orang meninggal. Sedangkan jumlah kasus Covid-19 terkonfirmasi positif di Majalengka sebanyak 10.733 orang, 10.452 orang sembuh, 69 orang dalam perawatan, dan 212 orang meninggal (Kawal Covid-19, 2021).

Gejala klinis yang muncul akibat terinfeksi virus Covid-19 seperti gejala flu biasa (demam, batuk, pilek, nyeri tenggorokan, nyeri otot, nyeri kepala) hingga komplikasi berat (diare dan pneumonia) hingga menyebabkan kematian (Jabar, 2021). Anak-anak termasuk ke dalam kelompok usia yang sangat rentan terhadap penularan COVID-19 dari lingkungan sekitarnya. Sebagian anak-anak yang terinfeksi COVID-19 seringkali tidak menunjukkan gejala infeksi (Huang, C; Wang, Y; Li, X; Ren, L; Zhao, J; Hu, Y; Cao, 2020).

\section{MASALAH}

Hasil wawancara dengan Kepala Taman Kanak-kanak (TK) Fajar Indah diperoleh informasi bahwa dalam masa pandemi COVID-19 saat ini, anak-anak sangat membutuhkan pendampingan dalam menerapkan perilaku hidup bersih dan sehat selama masa pandemi COVID-19 karena tingginya resiko untuk terpapar penyakit. Anak-anak dalam kondisi saat ini seyogyanya mendapatkan perhatian khusus tentang cara pencegahan dan penularan COVID19. Hanya saja keterbatasan sumber informasi baik dari orang tua, pengajar, ataupun media lainnya membuat mereka masih perlu mendapatkan bimbingan untuk menerapkan perilaku hidup bersih dan sehat (PHBS) yang menjadi protokol dalam pencegahan COVID-19.

Berdasarkan hasil Survei Dasar Kesehatan Masyarakat (SDKM) PBL 1 kepada kelompok dasawisma RT 06 RW 02 Desa Cipaku menunjukkan bahwa data perilaku 
JURNAL PEMBERDAYAAN DAN PENDIDIKAN

KESEHATAN

VOL. 01 No. 01, DESEMBER 2021

DOI:
Ciptaan disebarluaskan di bawah

Lisensi Creative Commons

Atribusi-NonKomersial-

BerbagiSerupa 4.0 Internasional

masyarakat yang tidak mencuci tangan memakai sabun selama 20 detik berjumlah $100 \%$, yang tidak mencuci tangan setelah memegang handle pintu/tangga berjumlah $100 \%$, yang tidak mencuci tangan setelah bersentuhan 100\%, yang tidak mencuci tangan setelah batuk menggunakan tangan $100 \%$. Selain itu, perilaku physical distancing menunjukkan jumlah responden yang menghindari kerumunan sebanyak 70\%, yang menjaga jarak minimal 76,7\%, dan yang belajar/bekerja dari rumah tidak ada, artinya 100\% masyarakat beraktivitas rutin diluar rumah (SDKM, 2021).

\section{METODE PELAKSANAAN}

Metode yang digunakan dalam kegiatan ini adalah metode kaji tindak (Action Research) dengan pendekatan program tindak partisipatif (Partisipatory Action Program) melalui beberapa kegiatan diantaranya mengadakan perlombaan mewarnai pada pembelajaran dengan tema "Cuci Tangan Pakai Sabun (CTPS)", edukasi melalui poster tentang PHBS, dan praktik langsung cuci tangan pakai sabun. Adapun sasaran pada kegiatan yaitu anak-anak Taman Kanak-kanak (TK) Fajar Indah sebanyak 51 orang. Kegiatan pengabdian masyarakat dilaksanakan pada tanggal 26 Agustus 2021 di Taman Kanak-Kanak (TK) Fajar Indah Desa Cipaku, Kecamatan Kadipaten, Kabupaten Majalengka.

Tahapan kegiatan ini terdiri dari tahap persiapan, pelaksanaan, dan evaluasi. Tahap persiapan meliputi identifikasi masalah yang dilakukan dengan teknik wawancara dan observasi ke Taman Kanak-Kanak (TK) Fajar Indah, penyiapan materi oleh fasilitator, dan persiapan media edukasi berupa poster bergambar. Tahapan pelaksanaan meliputi penyampaian materi edukasi tentang PHBS dan lomba mewarnai bersama anak-anak TK dengan tema Cuci Tangan Pakai Sabun (CTPS). Penyampaian materi dilakukan dengan memberikan penyuluhan, pendampingan, serta bimbingan mengenai perilaku hidup bersih dan sehat (PHBS) menggunakan metode ceramah, tanya jawab, diskusi, dan demonstrasi. Adapun materi yang disampaikan mengenai pencegahan COVID-19, cara mencuci tangan yang baik dan benar, cara memakai masker, cara menerapkan etika batuk, dan cara melakukan Physical Distancing (menjaga jarak fisik).

Tahapan evaluasi meliputi penilaian pengetahuan peserta mengenai PHBS dalam pencegahan COVID-19. Tahap evaluasi (penilaian) dilakukan sebelum dan sesudah peserta mendapatkan edukasi mengenai PHBS. Kegiatan evaluasi bertujuan untuk mengetahui 
JURNAL PEMBERDAYAAN DAN PENDIDIKAN

KESEHATAN

VOL. 01 No. 01, DESEMBER 2021

DOI:
Ciptaan disebarluaskan di bawah

Lisensi Creative Commons

Atribusi-NonKomersial-

BerbagiSerupa 4.0 Internasional.

pengaruh kegiatan edukasi terhadap pengetahuan peserta mengenai PHBS dalam pencegahan COVID-19. Metode evaluasi yang digunakan adalah menggunakan angket (kuisioner) dan observasi. Angket berisi sejumlah pertanyaan tentang pengetahuan peserta mengenai PHBS dalam pencegahan COVID-19.

Berikut disajikan bagan kerangka penyelesaian masalah sebagai berikut :

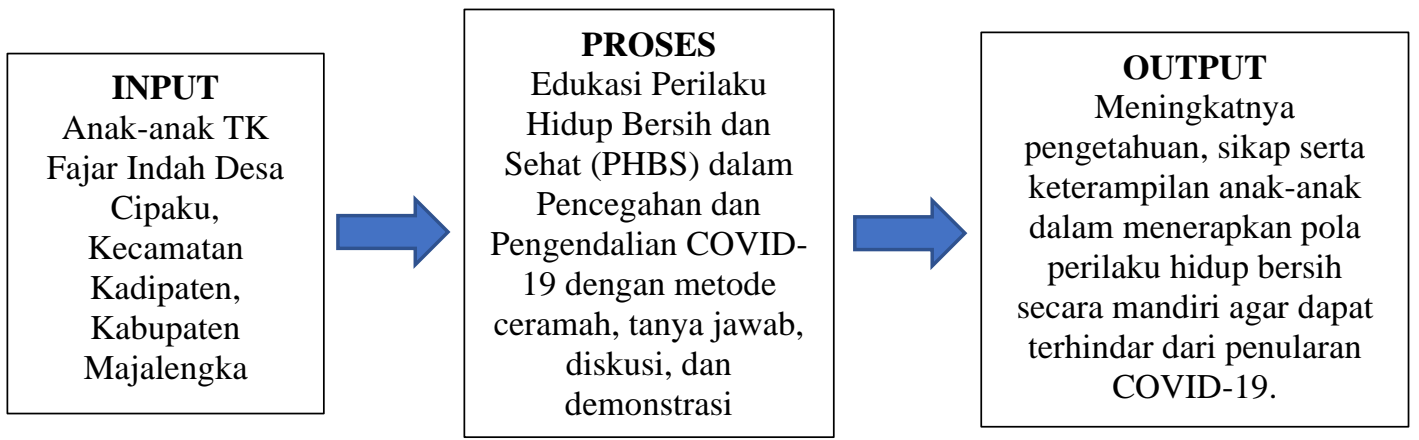

Gambar 1. Skema Kerangka Penyelesaian Masalah

\section{HASIL DAN PEMBAHASAN}

\section{Edukasi Mengenai PHBS dalam Pencegahan COVID-19}

Pelaksanaan kegiatan edukasi Perilaku Hidup Bersih Dan Sehat (PHBS) dalam pencegahan COVID-19 di Taman Kanak-kanak (TK) Fajar Indah Desa Cipaku telah terlaksana dengan baik mulai dari tahap persiapan hingga tahap evaluasi. Kegiatan ini dilakukan dengan memberikan pengetahuan kepada anak-anak TK Fajar Indah mengenai COVID-19 dan gejalanya, serta memberikan pendampingan dan bimbingan dalam menerapkan perilaku hidup bersih dan sehat agar terhindar dari COVID-19. Perilaku hidup bersih dan sehat (PHBS) yang diajarkan kepada anak-anak agar mereka terhindar dari COVID-19 adalah cara mencuci tangan yang baik dan benar, cara menerapkan etika batuk, cara melakukan jaga jarak fisik (Physical Distancing), dan cara menjaga kebersihan diri.

Kegiatan diikuti dengan antusias oleh peserta, hal ini dilihat dari keaktifan peserta dalam mengikuti kegiatan dari awal hingga akhir, keberanian peserta dalam menjawab pertanyaan yang diberikan oleh fasilitator, serta motivasi yang tinggi untuk belajar. Dalam kegiatan ini, tim pengabdian yang terdiri 5 orang mahasiswa Program Studi Kesehatan Masyarakat STIKes Kuningan. 
JURNAL PEMBERDAYAAN DAN PENDIDIKAN

KESEHATAN

VOL. 01 No. 01, DESEMBER 2021

DOI:
Ciptaan disebarluaskan di bawah

Lisensi Creative Commons

Atribusi-NonKomersial-

BerbagiSerupa 4.0 Internasional

Adapun media yang digunakan adalah poster bergambar. Media poster bergambar yang dipilih adalah poster berwarna yang memuat gambar/ilustrasi mengenai PHBS dalam pencegahan COVID-19. Poster-poster tersebut selanjutnya ditempel di beberapa bagian ruangan belajar agar anak-anak selalu ingat dalam menerapkan PHBS sehingga terhindar dari penularan COVID-19. Menurut (Hasnun, 2006), poster merupakan salah satu media berisi gambar atau tulisan di atas kertas atau kain yang berisi pemberitahuan (Arsyad, 2013). Media poster bergambar dipilih karena informasi yang ada di dalamnya disajikan dengan menarik dan mudah diingat bagi mereka yang melihatnya. Hal ini sesuai dengan pendapat (Agustin, 2017)yang menyatakan bahwa poster merupakan media kombinasi visual dari rancangan yang kuat, berwarna dan memiliki pesan dengan maksud untuk menangkap perhatian orang yang lewat, meskipun gagasan yang disampaikan membutuhkan waktu yang tidak singkat untuk tertanam dalam pikiran pembacanya (Hasnun, 2006).

Selain memberikan edukasi mengenai pengetahuan, peserta juga diajarkan untuk mempraktikkan secara langsung pengetahuan PHBS yang diperolehnya. Pada tahap ini, fasilitator mendemonstrasikan bentuk-bentuk PHBS dalam pencegahan COVID-19, kemudian anak-anak TK Fajar Indah diarahkan untuk melakukan praktik secara langsung mengenai cara cuci tangan pakai sabun. Menurut (Agustin, W. A; Supriyadi, 2007), fasilitator berperan dalam memberikan pengetahuan yang relevan kepada kelompok pemberdayaan masyarakat, sehingga kelompok sasaran mampu mencapai tujuan yang diinginkan (Rahmadeni et al., 2019).

\section{Perlombaan Mewarnai pada Pembelajaran}

Anak-anak Taman Kanak-kanak (TK) merupakan kelompok usia yang aktif bermain dan belajar. Untuk memudahkan diterimanya penyampaian materi oleh fasilitator, diperlukan media lain selain penyuluhan dengan metode ceramah. Oleh karena itu, kegiatan edukasi ini disertai dengan perlombaan mewarnai. Edukasi PHBS Cuci Tangan Pakai Sabun melalui perlombaan mewarnai diharapkan dapat meningkatkan daya ingat anak-anak karena sambil berkreasi warna, juga melakukan proses mengingat tentang cara mencuci tangan pakai sabun yang baik dan benar. Pendidikan karakter itu mungkin akan terlaksana apabila karakter tersebut diajarkan dan ditanamkan maupun diintegrasikan dalam setiap pembelajaran (baik dalam kurikulum, strategi pembelajaran, penciptaan atmosfer, adanya role model/teladan figur, maupun evaluasi pembelajarannya) dan sinergi orang tua, sekolah, dan masyarakat (Agustin, W. A; Supriyadi, 2007). Bahkan Risnawati (2012) menyimpulkan pada usia dini pendidikan 
JURNAL PEMBERDAYAAN DAN PENDIDIKAN

KESEHATAN

VOL. 01 No. 01, DESEMBER 2021

DOI:
Ciptaan disebarluaskan di bawah

Lisensi Creative Commons

Atribusi-NonKomersial-

BerbagiSerupa 4.0 Internasional

karakter anak dapat diberikan secara terpadu dalam ketentuan kurikulum dan melalui permainan di sentra main peran, pendidikan karakter anak dapat dioptimalisasikan (Suyadi, 2012).

Perlombaan mewarnai diikuti dengan antusias oleh para peserta penyuluhan. Diakhir acara, kami juga memberikan penghargaan bagi pemenang lomba dan seluruh peserta. Edukasi PHBS yang diberikan merupakan bentuk kegiatan yang tidak hanya sekedar memberikan pengetahuan semata, melainkan juga memberikan keterampilan melalui pembimbingan agar anak-anak Taman Kanak-kanak dapat menerapkannya secara mandiri dalam kehidupan seharihari. Kegiatan ini merupakan bentuk kegiatan pendidikan yang secara informal diharapkan dapat mempengaruhi pengetahuan, keterampilan dan sikap/perilaku peserta. Hal ini sesuai dengan pendapat Hamalik (2010) yang menyatakan bahwa pendidikan merupakan suatu usaha yang bertujuan untuk mempengaruhi peserta didik dalam menyesuaikan diri dengan lingkungannya, sehingga menimbulkan perubahan dalam dirinya agar dapat berfungsi secara kuat dalam kehidupan masyarakat (Risnawati ,2012).

Secara berkelanjutan edukasi ini diharapkan dapat menjadi perilaku hidup yang dapat diterapkan secara disiplin oleh anak-anak TK Fajar Indah agar mereka terhindar dari COVID19. Menurut Kurniawan (2017), kegiatan edukasi yang diberikan kepada anak-anak dapat menjadi landasan dalam melakukan perilaku hidup bersih dan sehat (PHBS) untuk mencapai derajat kesehatan yang baik. Upaya memberikan pengetahuan (edukasi) tentang perilaku hidup bersih dan sehat dapat menjadi salah satu upaya untuk meminimalisir faktor resiko penularan COVID-19 kepada anak-anak (Hamalik, 2010). Dalam jangka panjang pengetahuan yang telah mereka peroleh dapat berkembang menjadi sebuah perilaku kemandirian dan menjadi suatu habitual (kebiasaan) untuk diterapkan dalam kehidupan mereka sehari-hari. Pola edukasi perilaku hidup bersih dan sehat yang diharapkan dapat berkembang dalam diri anak-anak TK Fajar Indah untuk melindungi diri dari penularan COVID-19 digambarkan pada Gambar 2. 


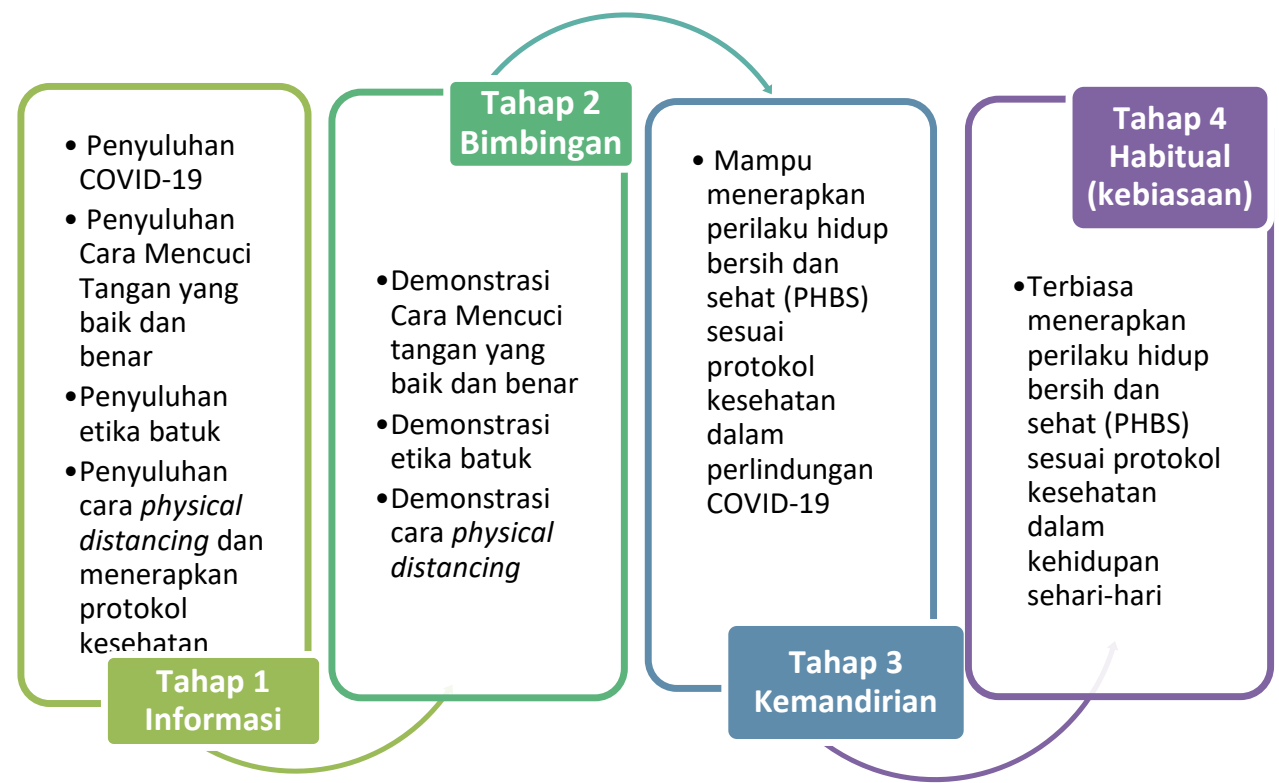

Gambar 2. Pola Kegiatan PHBS untuk Melindungi Diri dari COVID-19 bagi anak-anak

TK Fajar Indah

Peningkatan pengetahuan peserta mengenai PHBS dalam pencegahan COVID-19 diharapkan dapat diikuti oleh peningkatan sikap dan perilaku anak untuk menerapkannya secara mandiri. Oleh sebab itu kemandirian yang telah terdapat dalam diri mereka perlu didukung oleh keadaan lingkungan di sekitarnya. Menurut (Basri, 1995), pola asuh, kondisi sosial budaya, serta kondisi sosial ekonomi merupakan faktor eksternal yang mempengaruhi pembentukan kemandirian anak (Basri, 1995).

\section{Evaluasi Kegiatan}

Evaluasi kegiatan bertujuan untuk mengetahui perubahan pengetahuan peserta mengenai PHBS dalam pencegahan COVID-19 antara sebelum dan sesudah diberikan materi. Sebelum peserta diberikan materi pengenai PHBS dalam pencegahan COVID-19, peserta diminta mengisi lembar angket yang berisi sejumlah daftar pertanyaan mengenai PHBS. Setelah diberikan angket di awal, fasilitator menyampaikan materi dan mendemonstrasikan contoh perilaku hidup sehat. Kemudian, peserta diminta kembali mengisi angket di akhir kegiatan. Hasil evaluasi pengetahuan siswa mengenai PHBS dalam pencegahan COVID-19 sebelum dan sesudah diberikan materi penyuluhan dapat dilihat pada tabel 1 . 
Tabel 1. Distribusi Frekuensi

\begin{tabular}{lllll}
\hline & \multicolumn{2}{l}{ Sebelum Penyuluhan } & \multicolumn{2}{l}{ Sesudah Penyuluhan } \\
\hline Pengetahuan & Frekuensi & Persentase (\%) & Frekuensi & Persentase (\%) \\
\hline Kurang & 47 & 92.2 & 0 & 0 \\
Cukup & 4 & 7.8 & 10 & 19.6 \\
Baik & 0 & 0.00 & 41 & 80.4 \\
\hline Total & 51 & 100 & $\mathbf{5 1}$ & $\mathbf{1 0 0}$ \\
\hline
\end{tabular}

Berdasarkan hasil dari tabel 1 dapat diketahui bahwa tingkat pengetahuan responden sebelum diadakannya penyuluhan sebagian besar memiliki pengetahuan yang kurang yaitu sebanyak 47 orang (92.2\%), dan yang memiliki pengetahuan cukup sebanyak 4 orang (7.8\%). Sedangkan setelah diadakannya penyuluhan, sebagian besar responden memiliki pengetahuan baik yaitu sebanyak 41 orang $(80.4 \%)$ dan yang berpengetahuan cukup sebanyak 10 orang (19.6\%). Sehingga dapat disimpulkan bahwa adanya perubahan pengetahuan mengenai PHBS dalam pencegahan COVID-19 dari sebelum dan sesudah penyuluhan dilakukan.

Tabel 2. Uji Normalitas

\begin{tabular}{lllllll}
\hline & \multicolumn{3}{l}{ Kolmogorov-Smirnov } & \multicolumn{3}{l}{ Shapiro-Wilk } \\
\hline & Statistic & Df & Sig. & Statistic & Df & Sig. \\
\hline Pre Test & 535 & 51 & 000 & 299 & 51 & 0,000 \\
Post Test & 492 & 51 & 000 & 486 & 51 & 0,000 \\
\hline
\end{tabular}

Berdasarkan tabel 2 diatas dapat diketahui bahwa hasil dari uji normalitas (Kolmogorov Smirnov dan Shapiro Wilk) dari setiap data (pre test dan post test). Nilai probabilitas yang didapatkan adalah 0,000 atau lebih kecil dari 0,05 ( $<<0,05)$ maka dapat disimpulkan bahwa data tersebut tidak berdistribusi normal sehingga analisis data perlu dilakukan dengan uji wilcoxon. Adapun hasil uji wilcoxon sebagai berikut.

Tabel 3. Hasil Uji Wilcoxon pada Tingkat Pengetahuan Responden Sebelum Penyuluhan (Pre Test) dan Sesudah Penyuluhan (Post Test) PHBS Dalam Pencegahan COVID-19

\begin{tabular}{llll}
\hline Nilai Pengetahuan & Frekuensi & Mean Rank & P value \\
\hline Post-test $<$ Pre test & 0 & 0,00 & \\
Post-test $>$ Pre test & 51 & 26,00 & \multirow{2}{*}{0,000} \\
Post-test $=$ Pre test & 0 & 0,00 & \\
\cline { 1 - 3 } Total & $\mathbf{3 0}$ & & \\
\hline
\end{tabular}

Berdasarkan tabel 3 diatas dapat diketahui bahwa seeluruh responden memiliki nilai post test lebih besar dibandingkan dengan nilai pre test yaitu sebanyak 51 orang. Nilai probabilitas uji Wilcoxon berdasarkan tabel tersebut adalah 0,000 atau lebih kecil dari 0,005 (p $<$ 0,05), maka dapat disimpulkan bahwa ada pengaruh penyuluhan terhadap tingkat 
JURNAL PEMBERDAYAAN DAN PENDIDIKAN

KESEHATAN

VOL. 01 No. 01, DESEMBER 2021

DOI:
Ciptaan disebarluaskan di bawah

Lisensi Creative Commons

Atribusi-NonKomersial-

BerbagiSerupa 4.0 Internasional

pengetahuan anak-anak TK Fajar Indah desa Cipaku, yaitu dengan diadakannya penyuluhan dapat meningkatkan pengetahuan responden.

\section{KESIMPULAN}

Kesimpulan yang diperoleh dari pelaksanaan kegiatan pengabdian masyarakat ini adalah terdapat pengaruh penyuluhan terhadap tingkat pengetahuan anak-anak di Taman Kanak-kanak Fajar Indah desa Cipaku, dengan diadakannya penyuluhan dapat meningkatkan pengetahuan responden $(\mathrm{p}<0,05)$. Sebelum dilaksanakannya penyuluhan, jumlah peserta yang memiliki tingkat pengetahuan kurang sebanyak 47 orang (92.2\%) dan pengetahuan cukup sebanyak 4 orang (7.8\%) kemudian setelah dilaksanakannya penyuluhan, tingkat pengetahuan peserta meningkat menjadi berpengetahuan baik yaitu sebanyak 41 orang $(80.4 \%)$ dan berpengetahuan cukup sebanyak 10 orang (19.6\%).

\section{UCAPAN TERIMA KASIH}

Pelaksanaan kegiatan Edukasi Perilaku Hidup Bersih dan Sehat (PHBS) dalam Pencegahan dan Pengendalian COVID-19 Pada Anak-anak TK Fajar Indah Desa Cipaku Kecamatan Kadipaten Kabupaten Majalengka Tahun ini tidak terlepas dari kontribusi semua pihak yang telah membantu dalam terlaksananya sebuah kegiatan. Penyusun mengucapkan ucapan terima kasih sebesar-besarnya kepada Kepala Desa Cipaku, Kepala beserta seluruh guru Taman Kanak-Kanak (TK) Fajar Indah Desa Cipaku, para orang tua siswa, serta seluruh peserta yang terlibat dalam kegiatan ini.

\section{DAFTAR PUSTAKA}

Agustin, W. A; Supriyadi, S. N. (2007). Peran Fasilitator Dalam Pemberdayaan Masyarakat Pada Program Penataan Lingkungan Permukiman Berbasis Komunitas. Jurnal Sosiologi DILEMA, 32(1), 69-78.

Arsyad, A. (2013). Media pembelajaran; Edisi revisi.

Basri, H. (1995). Remaja Berkualitas: Problematika Remaja dan Solusinya. Pustaka Pelajar. Covid-19, K. (2021). Jumlah Kasus Covid-19 di Indonesia saat ini. https://kawalcovid19.id/

Hamalik, O. (2010). Proses Belajar Mengajar. PT Bumi Aksara.

Hasnun, A. (2006). Pedoman Menulis untuk Siswa SMP dan SMA. Andi.

Huang, C; Wang, Y; Li, X; Ren, L; Zhao, J; Hu, Y; Cao, B. (2020). Clinical features of patients infected with 2019 novel coronavirus in Wuhan, ChinaClinical features of patients 
JURNAL PEMBERDAYAAN DAN PENDIDIKAN KESEHATAN

VOL. 01 NO. 01, DESEMBER 2021

DOI:
Ciptaan disebarluaskan di bawah

$\underline{\text { Lisensi Creative Commons }}$

Atribusi-NonKomersial-

BerbagiSerupa 4.0 Internasional.

infected with 2019 novel coronavirus in Wuhan, China. The Lancet, 395(10223), 497506.

Jabar, P. (2021). Jumlah Kasus Covid-19 di Jawa Barat saat ini.

Kurniawan, H. (2017). Upaya Peningkatan Derajat Kesehatan Pada Anak Di Taman Kanakkanak Melalui Edukasi Perilaku Hidup Bersih Dan Sehat. Jurnal Pengabdian Masyarakat, Ipteks, 3(1), 9-16.

Rahmadeni, A. S., Hayat, N., Novia, R., Siska, D., \& Yunaspi, D. (2019). Penyuluhan Perilaku Hidup Bersih Dan Sehat Dan Pembagian Sembako Pada Anak Di Panti Asuhan Mahabbatul Haq Tanjung Uma Batam. Jurnal Abdimas Saintika, 1(1), 141-144.

Risnawati, V. (2012). Optimalisasi Pendidikan Karakter Anak Usia Dini Melalui Seentra Main Peran di Taman Kanak-Kanak Padang. Jurnal Pesona PAUD, 1(1).

SDKM, P. 1. (2021). Survei Dasar Kesehatan Masyarakat.

Singhal, T. (2020). A Review of Coronavirus Disease-2019 (COVID-19). The Indian Journal of Pediatrics, 87(4), 281-286.

Suyadi, R. (2012). Hasil Penelitian: Model Pendidikan Karakter pada Satuan Pendidikan Anak Usia Dini Islam. Yogyakarta: Universitas Islam Negeri Sunan Kalijaga. 